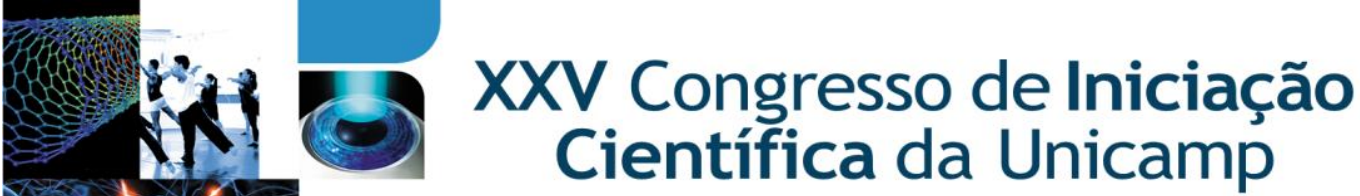

18 a 20 Outubro Campinas | Brasil

PRP ค

\section{Caracterização petrográfica das rochas hospedeiras e intrusivas do depósito de óxido de ferro-cobre-ouro Igarapé Cinzento (GT-46), Província Carajás.}

\section{Raul M. Arquaz*, Carolina P. N. Moreto, Poliana I. F. Toledo}

\section{Resumo}

O Depósito Igarapé Cinzento/GT 46 está localizado a NW da Serra de Carajás (PA), sobre a sequência meta-vulcano sedimentar arqueana do Grupo Grão Pará. Anfibolitos e meta-dacitos hospedam a mineralização e são intrudidos por tonalitos/granitos, granitos porfiríticos e diques de diabásio. Metamorfismo de facies anfibolito intermediário, alterações hidrotermais, texturas deformacionais e reações de substituição caracterizam a sequência das rochas hospedeiras.

Palavras-chave: Carajás, Depósitos IOGC, Metalogênese.

\section{Introdução}

O Domínio Carajás hospeda uma grande diversidade de depósitos de óxido de ferro-cobre-ouro (IOGC, Moreto et al. 2015). Nesses depósitos são reconhecidas extensas zonas de alteração hidrotermal, sugerindo intensa circulação de fluidos responsáveis por modificações significativas na mineralogia, textura e composição química das rochas hospedeiras da mineralização. $O$ depósito Igarapé Cinzento/GT-46 (Silva et al. 2005) está localizado na região noroeste da Serra dos Carajás dentro da sequência metavulcanossedimentar arqueana atribuída ao Grupo Grão Pará. O trabalho consistiu em caracterizar detalhadamente das rochas hospedeiras (anfibolitos e meta-dacitos) e intrusivas (tonalitos/ granitos, granitos porfiríticos e diques de diabásio intrusivos) com a finalidade de auxiliar na compreensão do modelo genético do depósito.

\section{Resultados e Discussão}

Os anfibolitos possuem uma coloração esverdeada, foliação discreta a bem marcada, granulação média e textura granonematoblástica. A assembleia mineral é constituída por anfibólio, plagioclásio, quartzo, biotita, resultado de pressões entre 300-400 MPa e temperaturas por volta de $600^{\circ} \mathrm{C}$ (Bucher \& Kurt 2011). Localmente, cristais de clinopiroxênio que são substituídos por hornblenda em reações de retrometamorfismo (Figura 1A). Minerais acessórios e de alteração (alanita, titanita, epidoto zircão, hastingsita, calcopirita, clorita e carbonato) são frequentes. A clorita preenche as fraturas dos cristais de anfibólio (Figura 1B) e transpõe a foliação em vênulas. As rochas meta-subvulcânicas dacíticas exibem uma coloração cinza, com foliação discreta a moderada, granulação fina a média, e texturas que variam de porfirítica a granular subédrica. São constituídas por biotita, plagioclásio, quartzo e hornblenda. Minerais acessórios e de alteração consistem em actinolita, alanita, hastingsita, clorita e carbonato. A biotita exibe texturas do tipo kink band (Figura 1C) consequente de processos deformacionais. A clorita pode ocorrer substituindo a biotita. Os tonalitos a granitos intrusivos possuem cores que variam de branco a esverdeado, com foliação discreta, de granulação fina a média e exibem textura granular subédrica. A composição mineral é restrita a plagioclásio, quartzo e biotita. Calcopirita ocorre como mineral de alteração e clorita, em vênulas discordantes. Além disso, vênulas de biotita com epidoto associado transpõem a foliação (Figura 1D). O granito porfirítico possui uma coloração branca a rosa, é isotrópico e exibe textura granular subédrica e de intercrescimento lamelar. É composto por plagioclásio, feldspato alcalino, quartzo e biotita. Ademais, a substituição da biotita por clorita é evidente (Figura 1E). O diabásio intrusivo é isotrópico, possui cor preta, granulação média e textura subofítica (Figura 1F) bem evidente. A rocha é formada por anfibólio, plagioclásio, quartzo, clinopiroxênio e illmenita como acessório. A clorita ocorre preenchendo fraturas nos anfibólios.
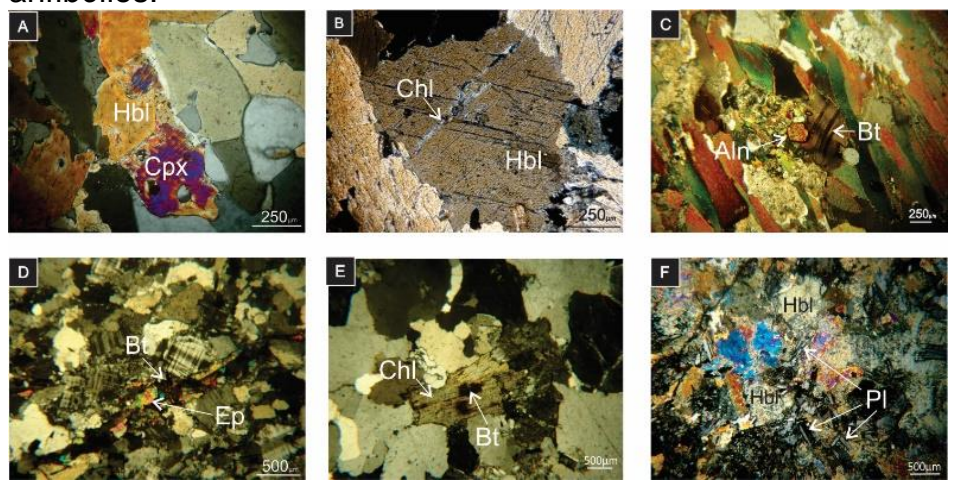

Figura 1. Rochas hospedeiras do depósito GT-46. A) clinopiroxênio ( $\mathrm{Cpx}$ ) parcialmente substituído por hornblenda (Hbl) no anfibolito; B) vênula de clorita cortando cristal de hornblenda no anfibolito; C) biotita (Bt) deformada apresentando textura kink band em meta-dacito; D) vênula com biotita e epidoto (Ep) em meta-dacito; E) biotita substituída por clorita (Chl) no granito porfirítico; F) textura subofítica preservada em dique de diabásio.

\section{Conclusões}

As rochas hospedeiras do depósito GT-46 passaram por deformações, metamorfismo regional em fácies Anfibolito e alterações hidrotermais com alta razão fluido/rocha que propiciaram mudanças significativas na composição mineralógica e textural dessas rochas

\section{Agradecimentos}

Os autores agradecem ao PIBlc/CNPq pela concessão da bolsa de iniciação científica. Esse projeto de pesquisa está vinculado aos projetos Fapesp (Processo 2016/13162-7) e CNPq (Auxílio à Pesquisa - Edital Universal 457689/20145) coordenados pela orientadora.

Bucher, K; Grapes, R. Petrogenesis of metamorphic rocks. 8 ed. New York: Springer, 2011. $428 \mathrm{p}$

Moreto C.P.N., Monteiro L.V.S., Xavier R.P., Creaser R.A., Dufrane S. A Melo G.H.C., Delinardo da Silva M.A., Tassinari C.C.G., Sato K. 2015b. Timing of multiple hydrothermal events in the iron oxide-copper-gold deposits of the Southern Copper Belt, Carajás Province, Brazil. Min. Deposita, vol. 50, p.517-546.

Silva M.G., Teixeira J.B.G., Pimentel M.M., Vasconcelos P.M., Arielo A.,Rocha W.J.S.F., 2005. Geologia e mineralizações de Fe-CuAu do Alvo GT46 (Igarapé Cinzento, Carajás), in Marini, O.J., Queiroz, E.T., Ramos, B.W. (eds.), Caracterização de Depósitos Minerais em Distritos Mineiros da Amazônia, DNPMFINEP-ADIMB, p. 94-151. DOI: 10.19146/pibic-2017-78832 